\title{
eHealth Literacy Scale: online version validation in italian
}

\section{Validazione italiana della eHealth Literacy Scale}

\author{
Walter De Caro ${ }^{1} \quad$ Elisabetta Corvo ${ }^{2} \quad$ Julita Sansoni ${ }^{3}$ \\ $1 \mathrm{Ph} . \mathrm{D}, \mathrm{RN}$, Research Fellow - Sapienza University of Rome \\ 2 Ph.D, MPH, JD, Lecturer - Canterbury Christ Church - Canterbury UK \\ 3 Professor of Nursing Science, Sapienza University of ROme
}

\section{INTRODUCTION}

The high number of health information that the web can provide together with the easy access and anonymity in the access encourages health researcher to try to understand the phenomenon. According to Norman \& Skinner, 2006 health information on the web may have negative effect on individuals' health, for instance wrong and incomplete health information on the web can lead to false reassurance or on the contrary to discomfort as result from incorrect diagnosis. This issues is particularly serious for young people who access the web quite easily but who did not have yet the ability to correctly evaluate health information and their quality level.

This study was aimed to validate in Italian the eHealth Literacy Scale (eHEALS) developed by Norman e Skinner in 2006. The scale is made up of 10 items has been validated in several different languages and according to Karnoe, A., \& Kayser, L., 2015 is widely used.

\section{METHOD}

A cross sectional study has been carried out. Data were gathered using the questionnaire translated in Italian, with a convenience sample of individuals of different facebook groups, excluding groups of health professionals. The study followed Gorsuch's recommendation stating as minimum sample to properly carry out a factorial analysis in 200 individuals.

\section{Instrument}

The original English version of eHEALS was developed as a scale for measuring perceived levels of ability of consumers to use technology to gather information about health.

The eHEALS is a tool of 10 items $(2+8)$ the first two additional items measure the perception of information on the internet in general while the other 8 measure combined the knowledge, consumer comfort and perceived ability to find, evaluate, and implement electronic health information. Individuals can assess their agreement/disagreement through a five point Likert scale ranging from "strongly disagree" to "strongly agree", with a score from 1 to 5 for each item for the 8 items thus, the scores could range from a minimum of 8 to a maximum of 40 , with higher scores representing higher levels of eHealth Literacy. For the first two item the Likert scale ranging from "Not useful at all" to "Very Useful" (item 1) and "Not important at all" and "Very important" (Item 2).

Psychometric assessment for eHEALS had a Cronbach's alpha of 0.86 , while a single factor solution with value 4.48 (56\% of variance explained) was obtained from analysis of the main components. The test-retest reliability made by Norman \& Skinner showed limited stability over time from baseline to 3 months of follow-up, with a Pearson correlation coefficient of 0.467 .

\section{Translation process}

The original version of the questionnaire, available for free, was translated having as main focus to get a conceptual translation rather than a linguistic one.

Forward-translations and back-translations were used (WHO, 2015) this is made up of 4 main phases:

a. Forward translation

b. Expert panel Back-translation

c. Pre-testing

d. Final version

Phase a) carried out by a nurse who was familiar with the topic, phase b) carried out by a panel of two experts who know both language Italian and English to sort out any kind of issues connected with different expression in the two languages, a comparison with the Spanish version (Paramio Gema Perez, 2015) was also carried out, this process produced the final version of the questionnaire, a back translation with an independent translator was also carried out, a number of discrepancies were sorted out. As far as Phase c) is concerned a pretest was carried out, the questionnaire was filled in by a sample of 10 individuals above 18 years old, female and male and with a range of different education level, the sample was asked to identify issues or problems in filling in and a statistical analysis was carried out. With 
respect to phase d) the final version of the Italian questionnaire was administered on line.

Data was gathered by both sending an email to individuals with internet mobile phone and to a number of facebook groups from September to November 2015, for test online validity of eHeals

The statistical analysis used for the development of the first eHEALS was used to properly compare the two questionnaire. Alpha di Cronbach was calculated and the SPSS software were also used, factorial analysis was carried out using Kaiser Meyer-Olkin test (KMO) as well as that of Bartlett.

\section{RESULTS}

The sample is made up of 737 individuals, of these 451 were female $(61.2 \%)$ (table 1$)$. The medium age is 41.4 years.

Table 1 - Gender

\begin{tabular}{c|cccc|}
\hline & Frequency & Percent & Valid percent & $\begin{array}{c}\text { Comulative } \\
\text { percent }\end{array}$ \\
Female & 451 & 61.2 & 61.2 & 61.2 \\
Male & 286 & 38.8 & 38.8 & 100 \\
Total & 737 & 100 & 100 & \\
\hline
\end{tabular}

The majority of the sample has an high school diploma (Table 2)

Table 2 - Sample education carateristhic

\begin{tabular}{c|cccc|}
\hline & Frequency & Percent & Valid percent & $\begin{array}{c}\text { Cumulative } \\
\text { percent }\end{array}$ \\
Other & 99 & 13.4 & 13.4 & 13.4 \\
PhD & 10 & 1.4 & 1.4 & 14.8 \\
$\begin{array}{c}\text { Registered in } \\
\text { the university }\end{array}$ & 36 & 4.9 & 4.9 & 19.7 \\
$\begin{array}{c}\text { Bachelor } \\
\text { degree }\end{array}$ & 57 & 7.7 & 7.7 & 27.4 \\
$\begin{array}{c}\text { MSc/MA } \\
\text { Junior High } \\
\text { School }\end{array}$ & 159 & 21.6 & 21.6 & 49 \\
\hline $\begin{array}{c}\text { High School } \\
\text { Total }\end{array}$ & 72 & 9.8 & 9.8 & 58.8 \\
\hline & 304 & 41.2 & 41.2 & 100 \\
\hline
\end{tabular}

Alpha di Cronbach is 0,862 which is aligned to literature on the topic, total items are positively correlated with high value (Table 3 ).

Table 3 - Statistical reliability

\begin{tabular}{|ccc|}
\hline Alfa di Cronbach & $\begin{array}{c}\text { Alfa di Cronbach's on } \\
\text { standardized value }\end{array}$ & Items \\
0.862 & 0.865 & 10 \\
\hline
\end{tabular}

Table 4 - Total Statistics for item

\begin{tabular}{|c|c|c|c|c|}
\hline & $\begin{array}{l}\text { Scale } \\
\text { mean if } \\
\text { item } \\
\text { deleted }\end{array}$ & $\begin{array}{l}\text { Scala } \\
\text { variance } \\
\text { if item } \\
\text { deleted }\end{array}$ & $\begin{array}{l}\text { Corrected } \\
\text { item - } \\
\text { Total cor- } \\
\text { relation }\end{array}$ & $\begin{array}{l}\text { Alpha di } \\
\text { Cronbach } \\
\text { if item } \\
\text { deleted }\end{array}$ \\
\hline $\begin{array}{l}\text { How useful do you feel the } \\
\text { Internet is in helping you in } \\
\text { making decisions about your } \\
\text { health? }\end{array}$ & 30.98 & 29.19 & 0.711 & 0.836 \\
\hline $\begin{array}{l}\text { How important is it for you to } \\
\text { be able to access health } \\
\text { resources on the Internet? }\end{array}$ & 30.65 & 32.314 & 0.577 & 0.848 \\
\hline $\begin{array}{l}\text { I know what health resources } \\
\text { are available on the Internet }\end{array}$ & 31.08 & 33.508 & 0.487 & 0.855 \\
\hline $\begin{array}{l}\text { I know where to find helpful } \\
\text { health resources on the } \\
\text { Internet }\end{array}$ & 31.03 & 33.009 & 0.573 & 0.849 \\
\hline $\begin{array}{l}\text { I know how to find helpful } \\
\text { health resources on the } \\
\text { Internet }\end{array}$ & 30.92 & 31.453 & 0.731 & 0.837 \\
\hline $\begin{array}{l}\text { I know how to use the } \\
\text { Internet to answer my que- } \\
\text { stions about health }\end{array}$ & 30.88 & 31.079 & 0.729 & 0.836 \\
\hline $\begin{array}{l}\text { I know how to use the health } \\
\text { information I find on the } \\
\text { Internet to help me }\end{array}$ & 30.89 & 31.239 & 0.64 & 0.843 \\
\hline $\begin{array}{l}\text { I have the skills I need to eva- } \\
\text { luate the health resources I } \\
\text { find on the Internet }\end{array}$ & 31.05 & 33.873 & 0.344 & 0.869 \\
\hline $\begin{array}{l}\text { I can tell high quality health } \\
\text { resources from low quality } \\
\text { health resources on the } \\
\text { Internet }\end{array}$ & 31.14 & 33.535 & 0.404 & 0.863 \\
\hline $\begin{array}{l}\text { I feel confident in using infor- } \\
\text { mation from the Internet to } \\
\text { make health decisions }\end{array}$ & 31.63 & 30.93 & 0.591 & 0.847 \\
\hline
\end{tabular}

Kayser Meyer Olkin test for sampling adequacy is 0.776 , which is higher to the value of 0,6015 , Bartlett test is statistically significant $(p<0,001)$ therefore data can used to a factorial analysis.

Table 5 - KMO and Bartlett's test

\begin{tabular}{|c|c|}
\hline Sampling adequacy KMO (Keiser Meyer Olkin) & 0.776 \\
\hline Chi-square appross. & 4229.421 \\
\hline \multirow{2}{*}{$\begin{array}{l}\text { Bartlett's Test of } \\
\text { Sphericity }\end{array}$} & 45 \\
\hline & 0.001 \\
\hline
\end{tabular}


Communalities are high (the proposed model explains a good proportion of variance), all items can be used to carry out a factorial analysis (higher to 0.5 ).

These results indicated that the data was appropriate for the exploratory factor analysis.

With respect to the components of the total variance, using the principal component analysis, a single solution with an eigenvalue of 4.66 represents $46,69 \%$ of the total variance.

Table 6 - Communalities

\begin{tabular}{|c|c|c|}
\hline & Initial & Extraction \\
\hline $\begin{array}{l}\text { I know what health resources are available on } \\
\text { the Internet }\end{array}$ & 1 & 0.582 \\
\hline $\begin{array}{l}\text { I know where to find helpful health resources } \\
\text { on the Internet }\end{array}$ & 1 & 0.884 \\
\hline $\begin{array}{l}\text { I know how to find helpful health resources on } \\
\text { the Internet }\end{array}$ & 1 & 0.803 \\
\hline $\begin{array}{c}\text { I know how to use the Internet to answer my } \\
\text { questions about health }\end{array}$ & 1 & 0.697 \\
\hline $\begin{array}{l}\text { I know how to use the health information I } \\
\text { find on the Internet to help me }\end{array}$ & 1 & 0.705 \\
\hline $\begin{array}{l}\text { I have the skills I need to evaluate the health } \\
\text { resources I find on the Internet }\end{array}$ & 1 & 0.853 \\
\hline $\begin{array}{l}\text { I can tell high quality health resources from } \\
\text { low quality health resources on the Internet }\end{array}$ & 1 & 0.82 \\
\hline $\begin{array}{l}\text { I feel confident in using information from the } \\
\text { Internet to make health decisions }\end{array}$ & 1 & 0.727 \\
\hline $\begin{array}{l}\text { How useful do you feel the Internet is in hel- } \\
\text { ping you in making decisions about your } \\
\text { health? }\end{array}$ & 1 & 0.761 \\
\hline $\begin{array}{l}\text { How important is it for you to be able to } \\
\text { access health resources on the Internet? }\end{array}$ & 1 & 0.699 \\
\hline
\end{tabular}

Extraction method: Principal component analysis
The first column are the various possible solutions, eigenvalues with a value higher than one are three, therefore three principal components are extracted, together with the $75.29 \%$ of the variance (table 7 )

All variables under consideration were positively correlated with the first principal component and the variables related to the use, evaluation and distinction of the main components are linked to the second component (table 8).

Table 8 Component Matrix.

\begin{tabular}{|c|c|c|c|}
\hline & \multicolumn{3}{|c|}{ Component } \\
\hline & 1 & 2 & 3 \\
\hline $\begin{array}{l}\text { I know what health resources are } \\
\text { available on the Internet }\end{array}$ & 0.606 & -0.02 & -0.463 \\
\hline $\begin{array}{l}\text { I know where to find helpful health } \\
\text { resources on the Internet }\end{array}$ & 0.675 & 0.363 & -0.545 \\
\hline $\begin{array}{l}\text { I know how to find helpful health } \\
\text { resources on the Internet }\end{array}$ & 0.81 & 0.255 & -0.285 \\
\hline $\begin{array}{l}\text { I know how to use the Internet to } \\
\text { answer my questions about health }\end{array}$ & 0.822 & -0.143 & -0.027 \\
\hline $\begin{array}{c}\text { I know how to use the health infor- } \\
\text { mation I find on the Internet to help } \\
\text { me }\end{array}$ & 0.73 & -0.209 & 0.359 \\
\hline $\begin{array}{l}\text { I have the skills I need to evaluate the } \\
\text { health resources I find on the Internet }\end{array}$ & 0.384 & 0.699 & 0.466 \\
\hline $\begin{array}{c}\text { I can tell high quality health resources } \\
\text { from low quality health resources on } \\
\text { the Internet }\end{array}$ & 0.447 & 0.742 & 0.264 \\
\hline $\begin{array}{c}\text { I feel confident in using information } \\
\text { from the Internet to make health } \\
\text { decisions }\end{array}$ & 0.692 & -0.338 & 0.366 \\
\hline $\begin{array}{c}\text { How useful do you feel the Internet is } \\
\text { in helping you in making decisions } \\
\text { about your health? }\end{array}$ & 0.824 & -0.284 & -0.039 \\
\hline $\begin{array}{l}\text { How important is it for you to be able } \\
\text { to access health resources on the } \\
\text { Internet? }\end{array}$ & 0.691 & -0.436 & 0.175 \\
\hline
\end{tabular}

\begin{tabular}{|c|c|c|c|c|c|c|}
\hline \multirow{2}{*}{ Component } & \multicolumn{3}{|c|}{ Eigenvalue at start } & \multicolumn{3}{|c|}{ Pesi dei fattori non ruotati } \\
\hline & Total & $\%$ of variance & $\%$ cumulated & Total & $\%$ of variance & $\%$ cumulated \\
\hline 1 & 4.669 & 46.691 & 46.691 & 4.669 & 46.691 & 46.691 \\
\hline 2 & 1.685 & 16.85 & 63.54 & 1.685 & 16.85 & 63.54 \\
\hline 3 & 1.175 & 11.755 & 75.295 & 1.175 & 11.755 & 75.295 \\
\hline 4 & 0.657 & 6.574 & 81.87 & & & \\
\hline 5 & 0.465 & 4.648 & 86.518 & & & \\
\hline 6 & 0.452 & 4.519 & 91.037 & & & \\
\hline 7 & 0.33 & 3.302 & 94.339 & & & \\
\hline 8 & 0.269 & 2.691 & 97.03 & & & \\
\hline 9 & 0.179 & 1.794 & 98.824 & & & \\
\hline 10 & 0.118 & 1.176 & 100 & & & \\
\hline
\end{tabular}




\section{DISCUSSION}

This study was aimed to validate in Italian the eHealth Literacy Scale (eHEALS) developed by Norman e Skinner in 2006. Results provide support for both construct and validity in Italian. The factor analysis results found that all eight C-eHEALS were one factor. This is consistent with the original version of the scale, further support that this scale is able to measure a single construct of eHealth literacy. The concurrent validity of I-eHEALS has also been satisfactorily established as was consistent with other questionnaire which measure informatics competences, furthermore the I-eHEALS also demonstrated good internal consistency.

This study has several limitations, including the fact there is not as yet a gold standard for Health Literacy. In conclusion, the instrument I-eHEALS is a promising questionnaire to evaluate the eHealth Literacy. Considering its brevity, ease of administration and good psychometric properties, it is hoped that the results of this study will encourage further investigations with the use of I-eHEALS questionnaire for use among different age groups and gender in the Italian population. This tool is essential to facilitate further research on the development and testing of interventions that could raise health literacy to promote self-empowerment.

\section{BIBLIOGRAFIA}

Norman, C. D., \& Skinner, H. A. (2006). eHEALS: the eHealth literacy scale. Journal of medical Internet research, $8(4)$.

Karnoe, A., \& Kayser, L. (2015). How is eHealth literacy measured and what do the measurements tell us? A systematic review. Knowledge Management \& E-Learning: An International Journal (KM\&EL), 7(4), 576-600.

Paramio Pérez, G., Almagro, B. J., Hernando Gómez, Á., \& Aguaded Gómez, J. I. (2015). Validación de la escala eHealth Literacy (eHEALS) en población universitaria española. Revista Española de Salud Pública, 89(3), 329338.

World Health Organization (2015). Process of translation and adaptation of instruments, Avaible on http://www.who.int/substance_abuse/research_tools/translation/en/

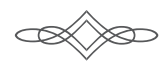

